\title{
DIGITAL ID AND RISK OF STATELESSNESS
}

\author{
GRACE MUtUnG’U AND ISAAC RUTENBERG*
}

TABLE OF CONTENTS

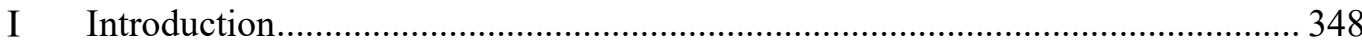

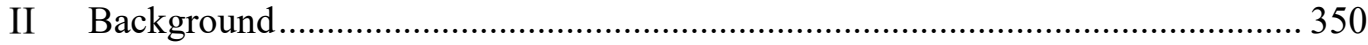

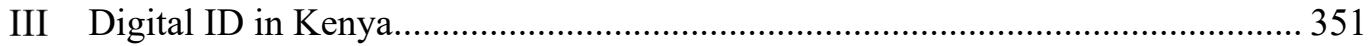

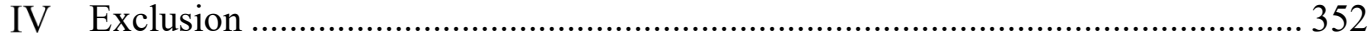

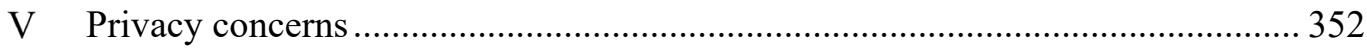

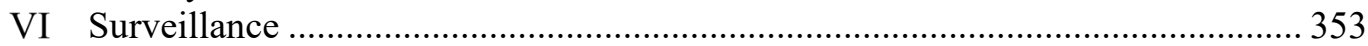

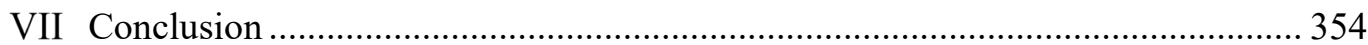

\section{INTRODUCTION}

State issued digital identity is trending in sub-Saharan Africa, ${ }^{1}$ and Kenya has not been left behind. The government of Kenya launched the National Integrated Identity Management System ('NIIMS') in March 2019.2 Dubbed 'Huduma Namba', which translates to 'service number' in Swahili, the programme envisages a centralisation of identity programmes and the issuance of new unique personal identifiers to all citizens and registered foreigners in Kenya, but it has not been without problems.

The legal situation for NIIMS is defined by an Executive Order, an amendment to the national ID law, Huduma Namba Regulations and a judgement from the High Court. Through Executive Order No 1 of 2018, the President directed the development of NIIMS to create and manage a central master population database, to be the 'single source of truth' on all Kenyan citizens and foreign nationals residing in Kenya. ${ }^{3}$ NIIMS was to serve as a reference point for personal data for Ministries, Departments and Agencies (MDAs) and other approved stakeholders.

Later in 2018, an amendment to the primary identity law, the Registration of Persons Act, was inserted into the Statute Law (Miscellaneous Amendments) Act, an omnibus bill containing amendments to over fifty other pieces of legislation. ${ }^{4}$ The onmibus bill was signed into law in January 2019. It expands the data

* Both of Centre for Intellectual Property and Information Technology Law at Strathmore University in Nairobi, Kenya.

1 Digital Identity Toolkit: A Guide for Stakeholders in Africa (Toolkit, World Bank Group 2014)

$<$ http://documents.worldbank.org/curated/en/147961468203357928/pdf/912490WP0Digit00 Box385330B00PUBLIC0.pdf>.

2 Statute Law (Miscellaneous Amendments) Act, 2018 (2019) CXXI Kenya Gazette Supplement No 161 (Acts No 18) (Republic of Kenya) 321 ('Statute Law (Miscellaneous Amendments) Act').

3 Executive Order No 1 of 2018 - Reorganisation of the Government of the Republic of Kenya (Kenya) 6. This executive order can be found at 'Executive Order No.1 of 2018 Reorganisation of the Government of the Republic of Kenya', The Elephant (Web Page) $<$ https://www.theelephant.info/documents/executive-order-no-1-of-2018-reorganisation-ofthe-government-of-the-republic-of-kenya/>.

4 See Registration of Persons Act, Cap 107 (1949) (Republic of Kenya) ('Registration of Persons Act'), as amended by the Statute Law (Miscellaneous Amendments) Act (n 2) 32126. 
collected during registration of persons and creates NIIMS as a central link to government services and some private services (notably banking and telecommunications) through digital ID. NIIMS also centralises the administrative work of issuing identity documents. This centralisation effectively shifts aspects of government services from their respective departments to the identity department, housed at the Ministry of Interior.

NIIMS was, under the enabling law, authorised to collect DNA and GPS data on each person, although collection of these two forms of data was halted by the court in an interim judgement. ${ }^{5}$ The same judgement allowed NIIMS to proceed with collecting other forms of identity data, however. ${ }^{6}$ The judgement arose from petitions challenging the design of NIIMS as a mandatory precondition for access to government services. Petitioners contested the lack of privacy and data protection, opacity in the technology behind the system and the lack of public participation in developing the NIIMS law. ${ }^{7}$ In the final ruling for the case, the High Court allowed the NIIMS project in principle, on the condition that 'an appropriate and comprehensive regulatory framework' was first enacted. ${ }^{8}$

In response, the government in October 2020 published two sets of subsidiary regulations, popularly known as 'Huduma Namba Regulations'.9 These regulations pronounce the NIIMS database as the primary source of identification in Kenya, ${ }^{10}$ and the Data Protection (Civil Registration) Regulations ('Data Protection Law') creates a legitimate basis for processing NIIMS data. ${ }^{11}$ These regulations were made by the executive; thus their substance was not debated in Parliament, despite their drastic impact. A previous attempt at a comprehensive digital ID law, which was known as the Huduma Bill and would have required approval by Parliament, ${ }^{12}$ seems to have been abandoned in favour of the regulations.

Concerns about exclusion remain. Everyone residing in Kenya, including children, are required to register for the system, yet not everyone has primary identity documents such as birth certificates or national identity cards, which are required for enrolment. In May 2019, the government undertook a 45-day mass enrolment programme, where people were required to present themselves for biometric enrolment. Those people without a primary identity document could not register. The Huduma Namba Regulations do not address the plight of those who lack documents and such people are consequently at risk of statelessness. ${ }^{13}$

$5 \quad$ Nubian Rights Forum v Attorney-General; Child Welfare Society (Interested Parties) [2020] eKLR, Consolidated Petitions No 56, 58 and 59 of 2019 (High Court of Kenya, Nairobi) [1047](I)-(II) ('NIIMS Case').

6 ibid [1047](III).

7 ibid [13].

8 ibid [1047](III).

9 The two regulations are the Registration of Persons (National Integrated Identity Management System) Rules (2020) Kenya Gazette Supplement No 176, Legal Notice No 195 (Republic of Kenya) ('Registration of Persons Rules'); Data Protection (Civil Registration) Regulations (2020) (Republic of Kenya) ('Data Protection Regulations').

10 Registration of Persons Rules (n 9) r 10.

11 Data Protection Regulations (n 9) reg 4.

12 Draft Huduma Bill (2019) (Republic of Kenya).

13 Christine Mungai, 'Kenya's Huduma: Data Commodification and Government Tyranny', $A l$ Jazeera (online, 6 August 2019) <https://www.aljazeera.com/indepth/opinion/kenyahuduma-data-commodification-government-tyranny-190806134307370.html $>$. 
The petitioners in the above NIIMS case have lodged an appeal against the decision of the High Court. ${ }^{14}$ They argued that without resolving underlying issues such as protection from government overreach or from unresolved claims on nationality and citizenship, Huduma Namba will disenfranchise and burden a substantial number of people. For example, one cannot purchase a mobile phone SIM card without an ID card. ${ }^{15}$ Since 2016 , children must have a birth certificate in order to attend school, ${ }^{16}$ yet one needs a national ID card to register their child's birth. ${ }^{17}$ The case of one of the petitioners, the Nubian Rights Forum, is a reflection of the difficulties that Kenyans from marginalised communities face in acquiring legal documentation in both analogue and digital systems.

\section{BACKGROUND}

Nubians in Kenya generally hold that they are Kenyan by virtue of having been in the country for over 100 years. ${ }^{18}$ Their ancestral home is in South Sudan, but a large group was settled in Kenya by the British after the First World War. They were allocated land in Nairobi's Kibera area.

Around the time that the Nubians arrived in Kenya, the British colonial government began issuing identity documents to Kenyan male adults. Authorised under the Native Registration Ordinance, ${ }^{19}$ identity cards were worn around the neck on a piece of string. The primary object of the ID, referred to as the Kipande, was the control of African labour and movement. ${ }^{20}$

Among information collected during registration was the clan and tribe of each subject. The register codified major Kenyan tribes and, since it was not recognised as Kenyan, the Nubian tribe was never codified. The lack of this code was used for many years to deny Nubians registration for identification by subsequent government administrations. ${ }^{21}$

14 The Nubian Rights Forum (first petitioner in the NIIMS Case (n 5)) filed a notice of appeal in February 2020. A hearing date has not been set at the time of this commentary being published. For more information, see Nubian Rights Forum, 'February in a Glance' (Press Release, 10 March 2020) <http://nubianrightsforum.org/2020/03/10/february-in-a-glance/>; @) NubianRights (Nubian Rights Forum) (Twitter, 23 September 2020, 5:17PM) $<$ https://twitter.com/NubianRights/status/1308666764046348288>.

15 As commented on by the High Court of Kenya. See NIIMS Case (n 5) [517].

16 The legal basis for this can be found in the Basic Education Act, No 14 of 2013 (Republic of Kenya) s 33(1).

17 The Birth and Death Registration Act, Act No 2 of 1928 (Republic of Kenya) ss 7 and 2 require nationality documents in order to register a birth.

18 'Nubian Community in Kenya v Kenya', Open Society Justice Initiative (Web Page) $<$ https://www.justiceinitiative.org/litigation/nubian-community-kenya-v-kenya $>$.

19 Native Registration Ordinance (1921) Law No 56 of 1921 (Republic of Kenya).

20 Juliet Atellah, 'Toa Kitambulisho! Evolution of Registration of Persons in Kenya', The Elephant (Blog Post, 14 June 2019) <https://www.theelephant.info/datastories/2019/06/14/toa-kitambulisho-evolution-of-registration-of-persons-in-kenya/>.

21 An Identity Crisis? A Study on the Issuance of National Identity Cards In Kenya (Study, Kenya National Commission on Human Rights 2007) <http://www.knchr.org/Portals/0/EcosocReports/KNCHR\%20Final\%20IDs\%20Report.pdf> ('An Identity Crisis?'). 
Nubians have made many attempts to get the government to address their statelessness, including through advocacy and litigation. ${ }^{22}$ The government included Nubians as an official tribe in the 2009 national census. ${ }^{23}$ In 2011, Nubians obtained a decision of the African Committee of Experts on the Rights and Welfare of the Child, ${ }^{24}$ advising the Kenyan government to take special measures to ensure the registration of Nubian children. Despite this, they, alongside other cases such as border communities, face a longer process in acquiring national ID. They must be vetted by security committees before their registration can be approved. ${ }^{25}$ They are also required to provide additional documents, such as grandparent's identity cards and proof of residence. ${ }^{26}$

According to testimony given during a hearing on the ongoing NIIMS petition, many Nubians lack documentation because the requirements and procedures for registration are unclear and uncertain. ${ }^{27}$ For almost a century, this has denied them freedom of movement, registration of property, access to economic opportunities and employment. Consequently, they have remained in the Kibera area, which is an informal settlement with limited access to facilities such as schools and hospitals. ${ }^{28}$

\section{DigitAL ID IN KENYA}

The rationale, objects and nature of the Huduma Namba digital ID project are mostly deduced from pronouncements of public officials, as government policy on digital ID is not published. ${ }^{29}$ Some of the stated benefits include: convenience, as Kenyans will no longer have to carry multiple identity documents; improved security, as security agencies can access data about persons at the touch of a

22 See, eg, 'Citizenship Paralegals' Nubian Rights Forum (Web Page) $<$ http://nubianrightsforum.org/citizenship-paralegals/>; Open Society Foundations, Namati and Nubian Rights Forum, Briefing Paper: Implementation of Nubian Minors $v$ Kenya (Briefing Paper, African Committee of Experts on the Rights and Welfare of the Child February 2014) <https://namati.org/resources/briefing-paper-implementation-of-nubianminors-v-kenya/>.

23 'Ethnic Affiliation', Kenya National Bureau of Statistics (Web Page, 22 March 2013) $<$ https://www.knbs.or.ke/ethnic-affiliation/>.

24 NIIMS Case (n 5) 16, citing Decision on the Communication by the Institute for Human Rights and Development in Africa and the Open Society Justice Initiative (on Behalf of Children of Nubian Descent in Kenya) against the Government of Kenya, ACERWC, Decision 002/Com/002/09 (22 March 2011) $<$ https://www.refworld.org/cases,ACERWC,4f5f04492.html> ('Children of Nubian Descent in Kenya').

25 Registration of Persons Act (n 4) s 8

26 Registration of Persons Rules (n 9) r 4(2)(b) allows registration officers to seek documents for proof of nationality. Registration officers typically demand grandparents identity cards, see NIIMS Case (n 5) [947].

27 @ Nubian Rights (Nubian Rights Forum) (Twitter, 25 September 2019, 7:57PM) $<$ https://twitter.com/nubianrights/status/1176797872634978305>, quoting Shafi Al Hussein as they were cross-examined for the NIIMS Case (n 5):

My problem with \#NIIMS is my community will be left out and not only Nubians but many minorities - we want to migrate together. The issues of discrimination should be addressed so that we can walk together - otherwise how can I be denied services?

\#HudumaNamba

28 Children of Nubian Descent in Kenya (n 24) 13 [59], 14 [65].

29 For example, in the NIIMS Case (n 5), in response to requests for information on the architecture of NIIMs, the government referred to the Government Enterprise Architecture, which does not specifically provide for the NIIMS architecture: at [426]. 
button; and deterrence for money laundering and terrorism activities resulting from the tracking of criminals. ${ }^{30}$

Digital ID is also touted as a solution to long standing challenges regarding nationality. Per the government, non-Kenyans from surrounding countries have acquired the national identity card fraudulently while others have non-genuine ID. ${ }^{31}$ With centralisation of data, genuine Kenyan ID card holders have nothing to fear as their documents would be verified and permanently recorded in the master database. The fake ID holders would either have to prove their 'Kenyan-ness' or be locked out of the single source of truth. ${ }^{32}$

\section{EXCLUSION}

Considering that NIIMS dramatically reconceptualises access to government and other services, its legal basis in a three-clause amendment that received minimal public input and parliamentary debate is woefully inadequate. A comprehensive law would have provided an opportunity for dialogue on priorities in identity and inclusion in Kenya. Identity and inclusion experts have long called for resolution of the identity crisis, especially in a country that leaves border communities as well as Nubians at risk of statelessness. ${ }^{33}$ Such experts recommended digital ID with the understanding that priority would be given to persons without documentation so as to enhance their access to government services. ${ }^{34}$

However, the NIIMS project is clearly focused on serving those individuals already equipped with identity documents. ${ }^{35}$ The legal basis for NIIMS does not make provision for persons without identity documents. Yet, over the years, the provisions and practices of the Registration of Persons Act have contributed to the current situation for communities suffering from, or at risk of, statelessness. NIIMS has therefore been described as 'exclusion by design'. 36

Such issues of exclusion are, furthermore, not addressed by the Huduma Namba Regulations, which legitimise primacy of digital ID over any other form of identification. The regulations do not address issues regarding lack of documentation, but instead empower government bureaucracy to approve or reject primary documents presented to them. ${ }^{37}$

\section{PRIVACY CONCERNS}

The Statute Law (Miscellaneous Amendments) Act, which amends the Registration of Persons Act and authorises NIIMS, expands identity registration data to sophisticated biometric technology such as 'fingerprints, hand geometry, earlobe

30 'Government Proposes System That Will See Kenyans Carry Only Two ID Documents', Nation (20 April 2018) <https://nation.africa/kenya/videos/news/government-proposessystem-that-will-see-kenyans-carry-only-two-id-documents-1260696>.

31 NIIMS Case (n 55) [397].

32 @Haki_na_Sheria (Haki na Sheria) (Twitter, 3 October 2019, 12:38AM) <https://twitter.com/haki_na_sheria/status/1179405299071045638>.

33 An Identity Crisis? (n 21).

34 ibid.

35 'Frequently Asked Questions (FAQs)', Huduma Namba (Web Page) $<$ https://www.hudumanamba.go.ke/faqs/>.

36 @NubianRights (Nubian Rights Forum) (Twitter, 24 September 2019, 10:44PM) $<$ https://twitter.com/Haki_na_Sheria/status/1176477424286142464>, quoting Anand Venkatanarayanan as they were examined for the NIIMS Case (n 5).

37 Registration of Persons Rules (n 9) r 13. 
geometry, retina and iris patterns, and voice waves'. ${ }^{38}$ The amendment does not, however, specify the purposes for which data collected may be put to use, or other critical aspects of data protection.

The system is 'to create, manage, maintain and operate a national population register as a single source of personal information of all Kenyan citizens and registered foreigners resident in Kenya'. ${ }^{39}$ It authorises public officers mandated by the Minister to inspect the register and make extracts therefrom. ${ }^{40}$ No further details on the principles or safeguards to be applied in accessing the register exist. NIIMS has been defined as purpose-free, ${ }^{41}$ The problem is compounded by the lack of operationalisation of the Data Protection Law, which was enacted in 2019 during the NIIMS case.

Despite these risks, a significant number of people turned up for the mass registration drive. Cursory interviews revealed that many registered for fear of missing out on government services. ${ }^{42}$ After the mass registration drive for Huduma Namba, the government reported to have registered approximately 38 million people, an extraordinary number considering the estimated population of Kenya (possibly 45-50 million) and the high percentage of the population under the age of six (and exempt from registering).

Among those who complied with government calls to register were people from communities at risk of statelessness such as Nubians, border communities and Kenyan Arabs. Many also enrolled their children, hoping that by registering, they would save their children from the hurdles their parents and grandparents overcame to obtain identity documents. The consequences of not having identity documents are so dire that such people readily follow any instructions that promise to resolve their nationality status. Privacy concerns become secondary.

\section{SURVEILLANCE}

Arising from these privacy concerns is the system's surveillance potential as NIIMS collates all information related to the registration of persons. This function is further enhanced by the printing and collection of all manner of identity documents. ${ }^{43}$ The centralisation of the printing and distribution of ID documents intersects with security functions historically attributed to the national identity card. ${ }^{44}$ Yet, there are other identity services that are not directly related to security services, but are instead related to social services such as health insurance and social security.

38 Registration of Persons Act (n 4) ss 3, 5 as amended by the Statute Law (Miscellaneous Amendments) Act (2018) (n 2) 321. The original amendment to these sections also specified 'Deoxyribonucleic Acid', but the provision was later expunged by the NIIMS Case (n 5).

39 Registration of Persons Act (n 4) s 9A(2)(a), as amended by the Statute Law (Miscellaneous Amendments) Act (n 2) 322.

40 Registration of Persons Act (n 4) s 9A, as amended by the Statute Law (Miscellaneous Amendments) Act (n 2) 322-25.

41 NIIMS Case (n 5) [63].

42 Joseph Muraya, 'Fear Drives Kenyans, Foreigners to Register for Huduma Namba 24 Hrs to Deadline', Capital News (online, $17 \quad$ May 2019 ) $<$ https://www.capitalfm.co.ke/news/2019/05/fear-drives-kenyans-foreigners-to-register-forhuduma-namba-24-hrs-to-deadline/ $>$.

43 These are listed in the Registration of Persons Act (n 4) s 9A(2)(d).

44 Kenya's Identity Ecosystem (Report, Caribou Digital 2019) $<$ https://www.cariboudigital.net/wp-content/uploads/2019/10/Kenyas-IdentityEcosystem.pdf $>$. 
Centralising the administration of all identity services exposes a person to the tracking of their life events and transactions with government. For example, a person's addition of dependants under their health insurance account is not only recorded in the database of the national insurance company, but also noted by the digital ID system as new identity documents are printed. Data about the person, such as their residential address, is also noted as the identity document is delivered to them. The person may also have to present themselves to the local authorities to collect the identity document. Some foreseeable complications in lumping social services with security functions include exposure of personal data regarding health or family relations, among others. ${ }^{45}$

Persons at risk of statelessness are often marginalised and in need of social services. Such services are best provided in a safe environment and without unnecessary engagement with law enforcement. The pursuit of social services should not put at risk an individual's legal and ethical right to privacy. Instead, their dignity should be protected and promoted. ${ }^{46}$ This would best be achieved by a digital ID system that protects their data from unwarranted access.

\section{CONCLUSION}

Legal identity is a fundamental right and a moral obligation owed by a country to the people within its borders. Prolonged statelessness is a failure of a state to address this right and obligation. The case of NIIMS clearly shows that basing a primary form of ID on the existence of other forms of primary ID will not solve the issue of statelessness, but will instead entrench it and all of its consequential issues.

Persons at risk of statelessness are often minorities who are different from the majority of the population in terms of ethnicity, place of origin or religion. They require higher protection to safeguard their human rights. For digital ID systems to achieve sustainable development goals in a holistic manner, they must include and prioritise those who have historically not been counted.

45 'Everyone Said No' Biometrics, HIV and Human Rights: A Kenya Case Study (Case Study, Kelin 2018) <https://www.kelinkenya.org/wpcontent/uploads/2018/07/\%E2\%80\%9CEveryone-said-no\%E2\%80\%9D.pdf>.

46 Magdalena Sepúlveda Carmona, Is Biometric Technology in Social Protection Programmes Illegal or Arbitrary? An Analysis of Privacy and Data Protection (ESS - Working Paper No 59, International Labour Organisation 2018) <https:/www.ilo.org/wcmsp5/groups/public/--ed protect/---soc sec/documents/publication/wcms 631504.pdf $>$. 